\author{
Sylwia Żakowska \\ Katarzyna Podhorodecka \\ ORCID 0000-0003-3075-7453 \\ Faculty of Geography and Regional Studies \\ Department of Regional and Political Geography \\ kpodhorodecka@uw.edu.pl
}

\title{
THE CORRELATION BETWEEN THE DISTRIBUTION OF TOURISM ASSETS AND THE LOCATION OF TOURIST ACCOMMODATION IN ŁÓDŹ PROVINCE ${ }^{1}$
}

\begin{abstract}
This article presents the correlation between natural and non-natural tourism assets and the distribution of tourist accommodation in the 24 powiats (districts) of Łódź Province. The authors, having divided these assets into natural and non-natural, discusses their occurrence in individual powiats. Next, tourist accommodation in Łódź Province is described, along with a presentation of statistical data. An important part of the paper is the presentation of the research results obtained by means of the point bonitation method. At the final stage, Spearman rank correlation coefficients is calculated, showing the strength of the relationship between selected tourism assets and the distribution of tourist accommodation.
\end{abstract}

Keywords: tourism asset, natural assets, cultural assets, tourist accommodation, tourism, Spearman's rank correlation.

\section{INTRODUCTION}

The article presents an analysis of the correlation between the distribution of tourist accommodation and the occurrence of natural and non-natural assets in Łódź Province. Tourism space appears as a consequence of tourism activity (WŁODARCZYK 2009), and tourist recreational attractions are found in areas with an interesting landscape, which are not overly urbanized, have a good climate and enable people to stay close to nature (KRUCZEK 2008).

The main aim is to provide an answer to the following question: which assets (natural or non-natural) have a stronger influence on the distribution of accommodation in Łódź Province? The author used the point bonitation method for research purposes. The results for tourism assets and the data on accommodation were correlated using Spearman's coefficient ${ }^{2}$. It was assumed that natural assets would have the strongest impact on the distribution of accommodation, particularly protected areas, close to which accommodation facilities would be likely to be built.

Relief, which determines the occurrence of other natural assets, is considered to be the most important. The elements which are important for tourists include the presence of water, its temperature and depth, and the type of shore. Vegetation and the animal world are significant, since they increase an area's attractiveness for all kinds of tourism activity (GOŁEMBSKI 2006). Spa infrastructure is linked to natural assets, geothermal waters and the general influence of the natural environment on human health. There are also natural elements in tourism that have been created or co-created by humans, such as historical parks, museums and natural history collections, botanical and zoological gardens. Although observation points are not tourism assets themselves, they provide an opportunity to make extensive observations and admire the landscape. Other assets are commonly found in large-scale forms of nature conservation: national parks, landscape parks and nature reserves (LIJEWSKI, MIKU-ŁOWSKI \& WYRZYKOWSKI 2002).

Non-natural assets - also known as human or cultural assets - are associated not only with history, archaeology, martyrdom or folklore, but also with the arts. Historical monuments of architecture, construction, business and technology, historical military buildings, as well as pilgrimage sites and contemporary cultural events, are human assets as well. According to A. KOWALCZYK (2001), tourists are more and more often visiting post-industrial monuments and technology-related sites. 


\section{LITERATURE REVIEW}

This section presents an overview of the information contained in the literature concerning natural and human assets, as well as the special character of industrial tourism. Two concepts which are closely related to tourism are leisure and recreation. Leisure usually takes some form of rest enabling people to regain their mental and physical strength. The term "recreation" refers to the process of regenerating one's strength and participating in cultural, sporting or other activities after work or school (in free time) (WARSZYŃSKA \& JACKOWSKI 1978).

According to T. JĘDRYSIAK (2008), tourism assets are often understood as tourist attractions, and, according to G. GOŁEMBSKI (2006), they contribute to tourist attractiveness. Other factors include the condition and protection of the natural environment and its accessibility. It is often emphasized that tourist attractiveness is an objective assessment made by tourists. According to S. WODEJKO (1997), the higher tourists' awareness is, the more important their assessment of attractiveness becomes. Most elements benefiting recreational tourism have been created by nature without human intervention (standing rocks, boulders, soil, landforms, caves, surface and underground water, ravines and valleys) (KUREK 2007). On the other hand, tourism assets can include various elements of the human environment depending on a tourist's interest (ROGALEWSKI 1972).

A major human asset is the variety of museums; they may be dedicated to famous people (biographical), history, archaeology, ethnography, art or technology. A particular type is the open-air museum, which not only preserves traditional rural buildings, but also cultivates customs, traditions and folk art. Important types of human asset are contemporary cultural events, particularly music and sporting events with more and more people are visiting cultural and entertainment locations such as theatres or philharmonic orchestras (KOWALCZYK 2001).

Another type of tourism which is important for Łódź Province is industrial tourism, which involves visiting areas where industry developed in the past. Examples include former mines, industrial plants, the facilities and equipment which made the development of technology possible, as well as old machinery and mills. Tourists are also interested in visiting museums of technology and industry, as well as enterprises which are still active (DEREK 2010).

According to J. KACZMAREK (2001), cities restructuring their economies after the decline of industry find themselves in a very difficult economic and social situation, and post-industrial tourism seems to present a good alternative when looking for new impulses for development and for sources of income for the inhabitants. At present, there are 1,630 sites listed on the European Industrial Heritage Route, 80 of which are located in Poland, including three in Łódź Province (the Manufaktura complex, the Central Museum of the Textile Industry and the EC1 complex) (www.erih. net). Industry began to develop in Poland in the $18^{\text {th }}$ century, but it was not until 100 years later that it flourished in Łódź. An important moment for the city was the year 1820, when a textile settlement was established (KRONENBERG 2012).

Recently, tourists have become increasingly interested in other technological achievements, for instance those connected with transport, such as old railway lines, train depots and narrow-gauge railways, which are being revitalized and used again (KOWALCZYK 2001).

Tourism is an economic phenomenon which provides an opportunity to show the culture of individual places. Tourism enables people to discover the cultural diversity of many regions and their inhabitants. However, the process of cultural diffusion, due to human interaction can also be seen (PRZECŁAWSKI 1997). Many authors that focus on tourism mention three models of attractiveness: '3S' (sea, sun, sand), ' $4 \mathrm{~A}^{\prime}$ (attractions, amenities, accommodation, access) and ' $3 \mathrm{E}^{\prime}$ (entertainment, excitement, education) (WIĘCKOWSKI 2014). Indeed, tourism in Łódź Province has much to offer, especially in terms of the ' $3 \mathrm{E}^{\prime}$ model.

Tourism supply can be compared to tourism attractiveness, as they have many features in common. To a large extent, it is tourism supply that determines the attractiveness of a region (WARSZYŃSKA \& JACKOWSKI 1978). It is understood as "the amount of a tourism product offered for sale at a given price and in a given period" (WODEJKO 1997). The area within which the tourism function develops is defined as tourism space. It is identified on the basis of the functions it performs and, according to B. WŁODARCZYK (2009), plays a leading role in tourism studies. J. WARSZYŃSKA \& A. JACKOWSKI (1978) define it is "the part of the geographical and socio-economic space in which tourism phenomena occur".

\section{NATURAL TOURISM ASSETS IN ŁÓDŹ PROVINCE}

Łódź Province consists of 24 powiats and 44 urban settlements, three of which have powiat status (Skierniewice, Piotrków Trybunalski, and the province capital - Łódź). The largest in terms of area and population is Łódź (293.25 km² and 693,800 inhabitants) ${ }^{3}$; second is Piotrków Trybunalski (67.24 km² and 74,900 people) (www.bdl.stat. gov.pl). Łódź Province covers 18,200 
$\mathrm{km}^{2}$, which is nearly $6 \%$ of the area of Poland. In terms of number of inhabitants, it is sixth nationally; however, the popula-tion of the province is constantly decreasing (www. stat.gov.pl/bdl) 4 .

Łódź Province is situated in the Central Polish Lowlands (Central Mazovian Lowland, South Wielkopolska Lowland and South Mazovian Hills), and partly in the Małopolska Upland and Silesian-Krakovian Upland (KRUCZEK 2005). The region lies in the centre of the country. The village of Piatek in the powiat of Łęczyca is considered to be the geometrical centre of Poland. In addition, near Stryków, two main transportation routes intersect - the A1 and A2 motorways.

Łódź region does not have a particularly varied relief; despite its upland character, there are not any distinctive hills. The highest of them - Kamieńska - is artificial and was created as a spoil heap from the "Bełchatów" brown coal mine at $386 \mathrm{~m}$ above sea level. The area has been forested and cultivated (www. lodzkie.travel.pl). The second highest is Fajna Ryba (374 m above sea level), in the gmina of Przedbórz, powiat of Radomsko.

Before 1820, Łódź Province had been densely forested. Due to the development of industry and the uncontrolled growth of the city and its suburbs, those assets have been irretrievably lost. Trees have been cut down and used for construction purposes and as fuel. Another purpose of deforestation was to obtain land for urban development. As a result, Łódź Province has the lowest afforestation (21.4\%) among all 16 provinces in Poland (A report on the condition of forests... 2017).

The development of industry largely contributed to the considerable degradation of the natural environment, both in Łódź itself and the entire Łódź Province (KOTER, LISZEWSKI \& SULIBORSKI 1999). Due to deforestation, water retention decreased, which has caused a lowering of the groundwater level. The condition of rivers has deteriorated over time which hampered the development of water-consuming industrial plants in the 1970s.

There are two artificial lakes in Łódź Province, Zalew Sulejowski on the River Pilica and Jeziorsko on the River Warta, both constructed in the second half of the $20^{\text {th }}$ century. Their surroundings have been adapted to the needs of tourism, with bathing sectors, beaches and forests (KOTER, LISZEWSKI \& SULIBORSKI 1999). Near the Sulejowski Reservoir is the Groty $\mathrm{Na}$ górzyckie reserve in Nagórzyce, as well as Niebieskie Źródła ('Blue Springs') within Tomaszów Mazowiecki. These magical, turquoise springs are the heart of a unique nature reserve (LIJEWSKI, MIKUŁOWSKI \& WYRZYKOWSKI 2002). The other reservoir, Jeziorsko, is less attractive for tourists, but it must be remembered that it is a sanctuary for many species of birds (LIJEWSKI, MIKUŁOWSKI \& WYRZYKOWSKI 2002) which is why a wildlife reserve, called Jeziorsko, has been established there.

In Łódź Province, we can find several well-known vegetation complexes of human origin. They include historical palaces surrounded with gardens, e.g. the baroque park in Nieborów or a romantic-sentimental park in Arcadia. The history of Nieborów goes back to the $12^{\text {th }}$ century but the palace and French garden surrounding it were not designed until the end of the $17^{\text {th }}$ century. The nearby park known as Arcadia features the following $19^{\text {th }}$-century buildings: a Temple of Sibyl, a Temple of Diana, aqueducts, a Gothic Cottage and Burgrave's House (www.nieborow.art.pl).

Another asset, natural and human at the same time, are botanical gardens, natural history museums and nature collections. Most of the botanical gardens in Poland are arboretums. One of them can be found in the town of Rogów which was created from scratch as an experimental unit of the Warsaw University of Life Sciences (SGGW) (ŁUKASZEWICZ 1987). It is one of the largest in Poland, a forest arboretum, and accommodates one of the richest and most interesting plant collections in Central and Eastern Europe. You can also visit the Museum of Forest and Timber there (www.arbore tum.sggw.pl).

Another human and natural site is Łódź Botanical Garden together with its Palm tree House, one of the largest in Poland. It covers 67 hectares and is a mixture of park and forest (www.uml.lodz.pl).

Particularly valuable areas, exceptional as regards nature, are protected by law. The method of point bonitation was used for three types: national parks, nature reserves and monuments of nature. The author discusses their presence in individual powiats as well as their influence on the distribution of tourist accommodation facilities. Landscape parks were considered to be of less importance and that is why they were not included in the analysis.

The main large-scale form of nature conservation is the national park. In Łódź Province, there is one such place, Polish Bison Breeding Centre in Smardzewice (powiat of Tomaszów), which was included in Kampinoski National Park in 1976. At present, it covers an area of $72.4 \mathrm{ha}$, and there are 20 breeding bison (OLACZEK 2013).

There are six nature reserves in Łódź Province whose purpose is to protect rare tree species. A unique tourism asset is the 'Forest of Apples' in the powiat of Piotrków. It covers 19 ha and was created to protect the variety of wild fruit trees which grow in the area. Alongside trees like oak, hornbeam, birch and rowan, wild apple and pear trees can be found there (OLACZEK 2013).

It is also interesting to visit reserves protecting commemorative tree stands. There are five of them in 
the province: Starodrzew Lubochniański, Gaik, Spała, Dęby in Meszcze and Uroczysko Bażantarnia (OLACZEK 2013). Zwierzyniec Królewski - a natural-landscape complex, covering an area of 572 ha, is a great attraction of the region as well (www.skierniewice.lodz.lasy. gov.pl).

The last group of assets that were analysed are monuments of nature. They may be individual trees, groups of trees, historical avenues, erratic boulders and exposed rocks, and grottos and caves (www. lodzkie.travel.pl). In 2016, there were 3,249 monuments of nature in Łódź Province. The most representative example is Źródliska Park in Łódź. Currently, it is divided into two parts, with Scheibler's (the greatest Łódź manufacturer) former factory and palace between them (www.kultura.lodz.pl; www.lodz.nasze miasto.pl).

\section{HUMAN TOURISM ASSETS IN ŁÓDŹ PROVINCE}

The appearance of modern Łódź has been determined by $19^{\text {th }}$ century architecture. The extraordinary development of industry at that time can still be traced in the cultural landscape, full of buildings made of characteristic red brick (MOKRAS-GRABOWSKA 2014). Older architectural monuments are situated outside the capital of the region.

There are many early medieval settlements in the province, for instance in Tum and Sieradz. The castles in Uniejów, Łęczyca or Piotrków Trybunalski, whose history contributes to the historical and cultural value of the region, were built on the site of ancient settlements. There are also noblemen's palaces, manor houses and residences, for example in Nieborów. In Skierniewice, there is the only Bishop's Palace in the region, built at the beginning of the $17^{\text {th }}$ century (KOTER, LISZEWSKI \& SULIBORSKI 1999).

Archaeological and ethnographic museums as well as open-air museums and folk culture centres appear across the whole Province. Elements of traditional folk culture are visible in the powiats of Łowicz and Opoczno, with their folklore recognized not only in Poland but also worldwide. An example of a village with historical houses is Złaków Borowy. In Łowicz, there is a museum where two traditional local farmsteads surround a yard. The tangible and intangible culture of Łowicz Księżaki is most fully presented in the open-air museum in Maurzyce near the town (LIJEWSKI, MIKUŁOWSKI \& WYRZYKOWSKI 2008).

Sacred architecture is one of the most important human assets. The oldest Romanesque churches in the Łódź region were built in the early $11^{\text {th }}$ century, e.g. the Collegiate Church in Tum (KRUCZEK 2005). Gothic churches were erected between the $14^{\text {th }}$ and $16^{\text {th }}$ centuries. In the centuries to follow, many other Catholic churches were built, mainly in the Baroque style. At the time of the Russian partition (19 ${ }^{\text {th }}$ century), Eastern Orthodox churches appeared in Łódź and Piotrków Trybunalski. The influx of German settlers, attracted by the developing textile industry, brought a number of Protestant churches, for instance in Łódź, Pabianice, Tomaszów Mazowiecki and Zduńska Wola (Augsburg-Evangelical, 19 ${ }^{\text {th }}$ century). The only example of an Evangelical Reformed temple is the church in Zelów (KOTER, LISZEWSKI \& SULIBORSKI 1999).

Urban plans dating back to different historical periods are yet another human asset of the Łódź region. Apart from the typical medieval spatial pattern, with a rectangular market square in the middle (e.g. Piotrków Trybunalski, Sieradz), there are also less common plans. A good example is Łowicz, famous for its two market places, including one in the shape of a triangle, or Łódź, which developed in the 19th century along Piotrkowska Street, starting from an octagonal market place, called Nowy Rynek (today's Plac Wolności).

The growing popularity of industrial and postindustrial tourism may turn out to be a great opportunity for Łódź. A considerable advantage of this type is the lack of clear seasonality which is rare in tourism (JĘDRYSIAK 2008). In recent years, run-down $19^{\text {th }}$-century factory complexes (manufacturers' villas and palaces, industrial plants, workers' housing estates) have been undergoing intensive revitalization. The best-known example is the transformation of Izrael Poznański's former factory into a shopping and entertainment centre, Manufaktura. Tourists may visit the museum of the factory and the Museum of Art $\left(\mathrm{ms}^{2}\right)$, and an industrialist's palace houses the Museum of the City of Łódź, opened in 1975 (KRONENBERG 2012). Currently, workers' houses are being renovated, and Księży Młyn - the largest factory complex in Łódź and the former property of Karol Scheibler, "the cotton king" - is undergoing revitalization.

The first post-industrial site open to tourists was Ludwik Geyer's former factory complex, currently housing the Central Museum of the Textile Industry. Many other post-industrial buildings, such as Karol Bennich's, Juliusz Kindermann's and Ernest Wever's factories, have found a use: some of them have been transformed into museums or art galleries, others into hotels or restaurants. The latest spectacular example of revitalization is the EC1 power plant in Łódź, which now hosts a modern Planetarium and the Science and Technology Centre. The facilities that are currently under construction include a Comic Book and Interactive Narrative Centre, as well as the National Centre of Film Culture. The whole complex is located near Łódź Fabryczna railway station (KRONENBERG 2012). 
Historical and military facilities are also considered to be significant human assets. An example is Kutno, with its Museum of the Battle of Bzura, or Konewka, near Spała, where visitors can see a German bomb shelter big enough to conceal an entire train from the Second World War. Tourists are also interested in enactments of historical battles, which were crucial for individual regions. Such reconstructions take place, for example, at Bolimów (1914) and Strońsk (1939).

A unique human asset of the region is the filmmaking heritage, both of Łódź itself (once regarded as the capital of the Polish film industry) and of many other localities in the province, which have been film sets for renowned Polish and foreign movies (especially Piotrków Trybunalski). In order to promote facilities and events referring to Polish film-making, a number of urban trails have been created (e.g. the "Fairy Tale Łódź" Trail or "Piotrków Trybunalski on Film"), as well as the regional Łódź Province Film Trail (Eódzkie filmowe), including one two-day and nine oneday trails for tourists using cars (KRONENBERG 2016).

Cultural events are the final human asset to be taken into consideration attracting inhabitants and tourists alike. Statistics show that in 2016, nearly 6000 cultural events were held in Łódź. Other powiats are not as attractive in this respect but those of Wieruszów and Pabianice (with under 3000 events) come next (www.bdl.stat.gov.pl). Examples of this kind of event include the Touring Festival of Łódź Philharmonic entitled "Colours of Poland", or the Light Move Festival which has already attracted over 600,000 spectators.

Other events which are worth mentioning include the Flower, Fruit and Vegetable Festival in Skierniewice (the oldest in Poland). Atlas Arena in Łódź (one of the largest and most modern sports and performance halls in the country) is a place where international volleyball and basketball matches, a variety of world music concerts, fashion shows, exhibitions and discussion panels take place.

\section{TOURIST ACCOMMODATION IN ŁÓDŹ PROVINCE}

All kinds of tourist facilities which serve the purpose of satisfying tourists' needs can be referred to as tourist infrastructure. Tourist accommodation resources may be divided into accommodation proper, catering, transport and accompanying services (SZWICHTENBERG 2000). In this analysis, the emphasis is put on accommodation, which is considered to be the basic measure of tourist supply. Used mostly by tourists, it is usually located in places with a high demand for services of this type (WODEJKO 1997). Moreover, hotels are often built in urban agglomerations. Accommodation services are included among typical tourist services, along with catering and transport, as well as organization, piloting and information services (KUREK 2007). The development of the hotel industry is noticeable when accommodation facilities of various sizes and types are built within a close distance of one another. Then, we are talking about an emerging tourist agglomeration (KOWALCZYK 2001).

Tourist accommodation has been divided by the World Tourism Organization (UN WTO), into hotel and accompanying (complementary) facilities. The former includes hotels, motels, boarding houses and inns. A further category consists of 'other accommodation facilities'. The UN WTO formulated the notion of 'a tourist accommodation facility', which is defined as 'any facility in which tourists regularly or occasionally stay for the night' (WODEJKO 1997). Group tourist accommodation includes hostels (also mountain shelters) and campsites (LIJEWSKI, MIKUŁOWSKI \& WYRZYKOWSKI 2002).

Statistical data concerning tourist accommodation in Eódź Province was obtained from the Local Data Bank of the Central Statistical Office. The information comes from 2017 and concerns both facilities which are open all year long and seasonal ones: $48.6 \%$ of group accommodation facilities in Łódź Province are hotels, and just $1 \%$ are motels.

Visitors are offered over 5000 beds in 31 hotels in Łódź. The second largest number can be found in the powiat of Zgierz (8 hotels, 563 beds), followed by the powiats of Piotrków Trybunalski and Pabianice, with 7 each. As regards the number of beds, in second place is the powiat of Zgierz (902) followed by Betchatów with 595 beds in just 5 facilities. Pensions can be found only in the powiats of Sieradz and Tomaszów, with 48 and 41 beds, respectively.

Other group accommodation facilities are situated in all the powiats of the province. The largest number of beds are available in Łódź (over 2,000) followed by Tomaszów with about 1,800 (www.bdl.stat.gov.pl).

\section{THE RULES FOR POINT BONITATION OF TOURISM ASSETS}

The bonitation method for assessing natural assets has been used in many publications (PIRASZEWSKA 2004, DRABAREK 2011, TERTELIS 2012). In this paper, in order to determine the overall value of the indicator, both human and natural assets are analysed. The more features distinguishing the region, the bigger the chance that tourists representing various tastes and interests will find something for them (GOŁEMBSKI 1999). It should be emphasised, however, that this method is partly subjective, and according to K. KOŻUCHOWSKI 
Tourism 2018, 28/2

Table 1. Points allocated for afforestation, legally protected areasand monuments of nature

\begin{tabular}{|c|c|c|c|c|c|c|c|c|}
\hline \multicolumn{9}{|c|}{ Point bonitation } \\
\hline $\begin{array}{c}\text { number } \\
\text { range } \\
(\%)\end{array}$ & $\begin{array}{c}\text { number } \\
\text { of bonitation } \\
\text { points }\end{array}$ & $\begin{array}{c}\text { number } \\
\text { of powiats }\end{array}$ & $\begin{array}{c}\text { number } \\
\text { range } \\
(\%)\end{array}$ & $\begin{array}{c}\text { number } \\
\text { of bonitation } \\
\text { points }\end{array}$ & $\begin{array}{c}\text { number } \\
\text { of powiats }\end{array}$ & $\begin{array}{c}\text { number } \\
\text { range } \\
\text { (number) }\end{array}$ & $\begin{array}{c}\text { number } \\
\text { of bonitation } \\
\text { points }\end{array}$ & $\begin{array}{c}\text { number } \\
\text { of } \text { powiats }\end{array}$ \\
\hline $0,1-10,0$ & 5 & 4 & $0,1-10,0$ & 2 & 5 & do 50 & 2 & 5 \\
\hline $10,1-20,0$ & 10 & 6 & $10,1-20,0$ & 4 & 9 & $51-100$ & 4 & 9 \\
\hline $20,1-30,0$ & 15 & 11 & $20,1-30,0$ & 6 & 7 & $101-200$ & 6 & 5 \\
\hline$>30,0$ & 20 & 3 & $>30,0$ & 8 & 3 & $>200$ & 8 & 5 \\
\hline
\end{tabular}

Source: authors.

(2005), the findings of evaluation analyses are never fully objective.

It is extremely difficult to assess the quality and value of individual assets, largely due to their subjective character but there are a number of indicators which define the quality of tourism assets. Natural assets include the following: forests, meadows and pastures, as well as other features in a gmina; rivers and lakes are classified according to purity classes; differences in height; average temperature and precipitations; the ratio of the protected landscape area to the total for a gmina; as well as tourist trails measured in kilometres per $100 \mathrm{sq}$. km. Human assets are defined by the number of major historical monuments, museums, fairs, exhibitions and events taking place in a gmina, and their incidence during the year (GOEEMBSKI 2006).

The bonitation scale is a relationship between a feature and a natural or human variable and the points it is allocated. Each of the studied elements of the environment is allocated a value. Three natural assets underwent a bonitation analysis: afforestation, legally protected areas and the number of monuments of nature (Table 1). Climate, precipitation and differences in height were not taken into account due to their in-sufficient diversification in individual powiats of Łódź Province.

Afforestation in the majority of powiats in central Łódź Province ranges from 20\% to 30\% (Fig. 1), which is close to the mean value for the whole region $(21.4 \%)$. Consequently, these powiats make up the largest group reaching the third out of a four-point scale, receiving 15 points. Three powiats (Tomaszów, Opoczno and Radomsko) obtained the maximum number of points (20), as forests cover more than $30 \%$ of their area. The least afforestation (below 10\%) was found in two powiats (Kutno and Łęczyca) and in two settlements with powiat status (Łódź and Skierniewice).

On the four-grade bonitation scale for protected areas, the powiats are distributed relatively evenly. In nine powiats, the protected areas accounted for $10-20 \%$, which gave them 6 out of a total of eight points. In seven powiats, such areas occupy $20.1-30 \%$ of the total area. The powiats of Brzeziny, Łask and Wieruszów demonstrate the highest percentage of legally protected area, exceeding 30\%. The smallest percentages were found in Kutno, Pajęczno and Zduńska Wola powiats, as well as in the urban powiats of Skierniewice and Łódź.

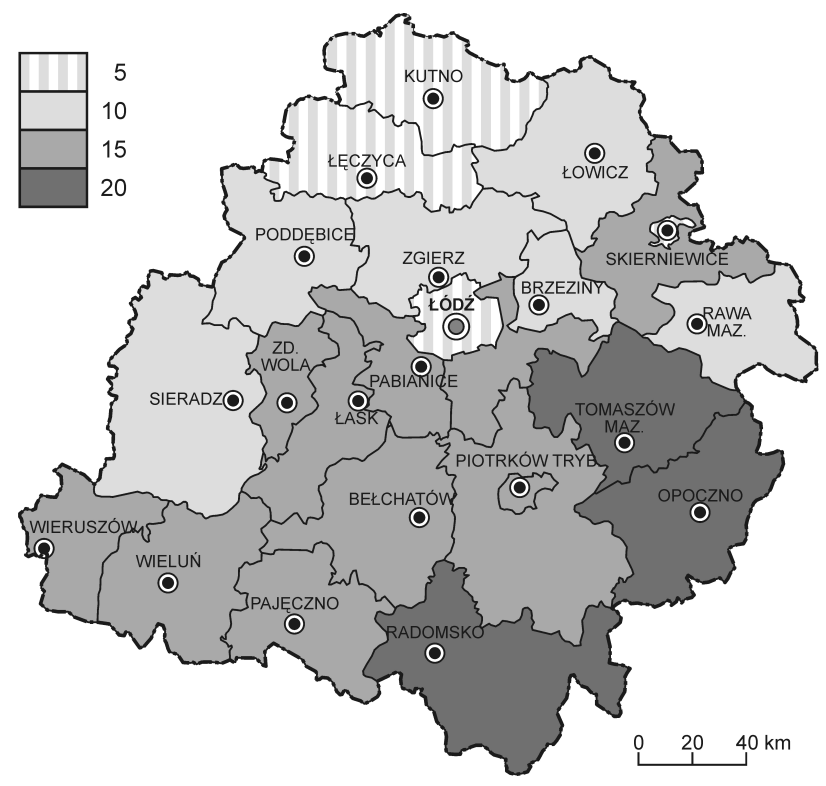

Figure 1. The number of bonitation points for afforestation in individual powiats of Łódź Province Source of Figures 1-7: authors

The analysis shows that the powiats of Łódź Province are not rich in legally protected areas (Fig. 2). Despite the fact that there is a scarcity of such areas in Skierniewice itself, there are many in the surrounding powiat, leading to six out of eight points on the bonitation scale. The distribution of monuments of nature in Łódź Province is uneven as well (Fig. 3). The most numerous group consists of nine powiats with 51 to 100 . The remaining three groups consist of five powiats each (up to 50, 10-200, and over 200 monuments). It is worth mentioning that there are 566 monuments of 
nature in the powiat of Tomaszów, which distinguishes it from those where the number does not exceed 300. The average for the province is 135 per powiat, which makes the Łódź region third highest in Poland. The situation is better only in Western Pomerania (on average, 140) and in Pomerania (on average, 141). Łódź Province can boast a total of 3,249 monuments of nature.

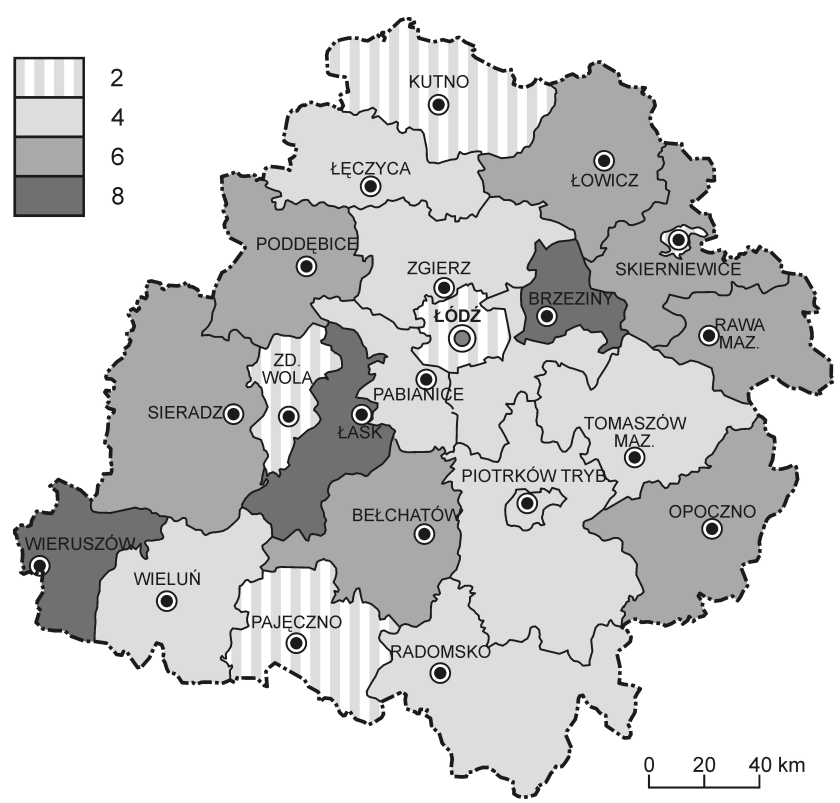

Figure 2. The number of the bonitation points for legally protected areas in particular poviats of Łódź Province

The powiats of Tomaszów and Radomsko obtained the best results in the point bonitation analysis of natural assets (each of them scored 32 out of 36 points). They were followed by the powiat of Opoczno, with 30 points. Kutno (9 points), Łęczyca (11 points) and the town of Skierniewice (11 points) were the three powiats with the poorest results. The average number of points received in all 24 powiats is 22 .

Three variables were used to conduct the analysis of human assets. One of them was the number of cultural events held in individual powiats of Łódź Province. The variable was chosen due to the growing

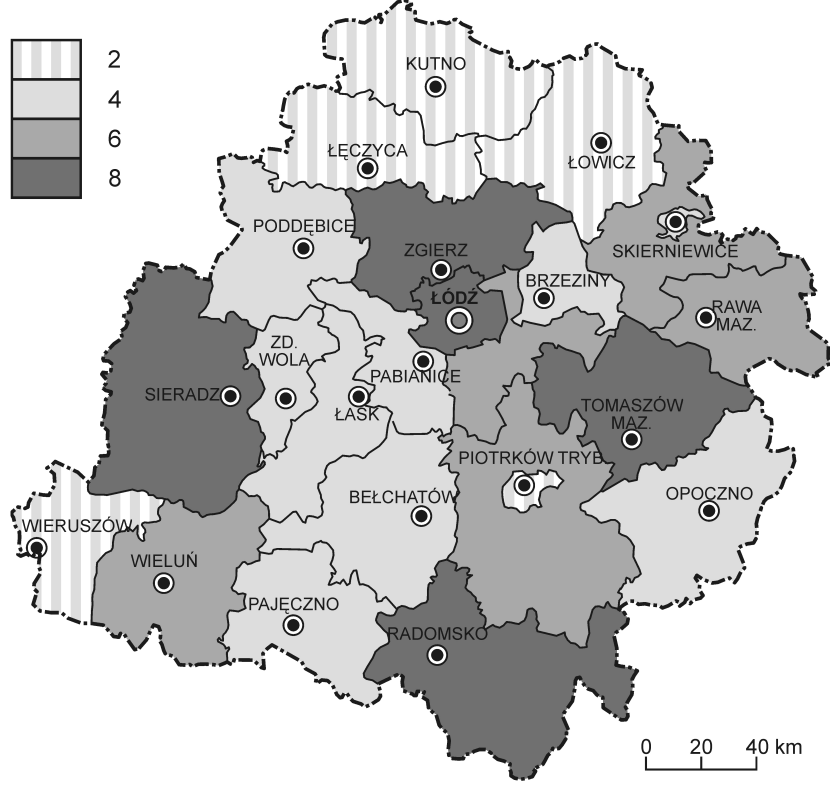

Figure 3. Bonitation points for the number of monuments of nature in individual powiats of Łódź Province

popularity of events, not only among local residents, but also tourists who are willing to see something typical of a given country or region. The second variable was the number of historical monuments in the powiats of Łódź Province. They include parks, manor houses, cemeteries, chapels, churches, town halls, belfries, avenues, as well as many other buildings performing a variety of functions. This type of asset is the most common among all available tourism assets. The third variable was historical sacred sites. They have already been included in the overall number of historical monuments, yet in this case they are specifically religious sites, such as Roman Catholic, Augsburg-Evangelical, Orthodox churches, and synagogues. Moreover, the category also includes historical chapels and belfries. Information concerning the number of cultural events and the number of historical monuments comes from 2016 and 2017. The data for historical sacred sites was found on the website dedicated to trips and tourism in Łódź Province, www.lodzkie. travel.pl.

Table 2. Point bonitation for the number of cultural events, historical monuments and sacred historical sites ${ }^{5}$

\begin{tabular}{|l|c|c|c|c|c|c|c|c|}
\hline \multicolumn{9}{|c|}{ Point bonitation for } \\
\hline $\begin{array}{c}\text { number range } \\
\text { (number) }\end{array}$ & $\begin{array}{c}\text { obtained } \\
\text { points }\end{array}$ & $\begin{array}{c}\text { number of } \\
\text { powiats }\end{array}$ & $\begin{array}{c}\text { number range } \\
\text { (number) }\end{array}$ & $\begin{array}{c}\text { obtained } \\
\text { points }\end{array}$ & $\begin{array}{c}\text { number of } \\
\text { powiats }\end{array}$ & $\begin{array}{c}\text { number range } \\
\text { (number) }\end{array}$ & $\begin{array}{c}\text { obtained } \\
\text { points }\end{array}$ & $\begin{array}{c}\text { number of } \\
\text { powiats }\end{array}$ \\
\hline $0-400$ & 5 & 9 & $0-50$ & 5 & 6 & $0-5$ & 5 & 4 \\
\hline $401-800$ & 10 & 6 & $51-100$ & 10 & 5 & $6-10$ & 10 & 6 \\
\hline $801-1200$ & 15 & 3 & $101-150$ & 15 & 9 & $11-15$ & 15 & 9 \\
\hline Over 1200 & 20 & 6 & over 150 & 20 & 4 & over 15 & 20 & 5 \\
\hline
\end{tabular}

Source: authors. 
According to the data included in Table 2, Łódź Province is a region where a relatively large number of cultural events take place. They include film shows, exhibitions, talks, meetings, theatre performances, conferences, competitions, workshops, festivals, concerts, sporting, recreational and outdoor events, museum classes or mass events widely covered in the media. The total number of the cultural events held in Łódź Province is almost 24,000, which is 10,000 more than the average number for the country as a whole. To compare, in 2016, slightly over 30,000 events were organized in Małopolskie Province, followed by Masovia with under 30,000 . In other provinces, the number of cultural events is about 20,000.

Most cultural events take place in Łódź and the surrounding powiats, especially those situated to the south of the city (Fig. 4). The largest number of points (20) was allocated to the powiat of Bełchatów, which is a region with substantial financial backing, allowing the local authorities to provide various forms of entertainment, not only for the inhabitants but also for visitors. The next group consists of powiats where the annual number of events ranges from 801 to 1200: the powiats of Łowicz, Rawa and Radomsko. The smallest number are held in the powiats of Sieradz, Poddębice, Łęczyca and Zduńska Wola.

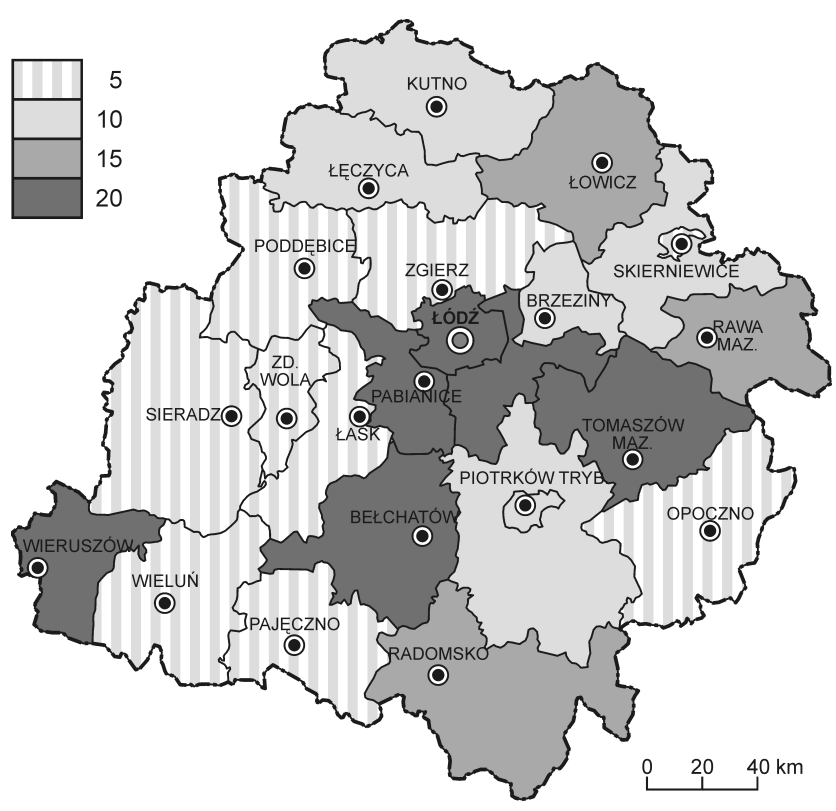

Figure 4. Bonitation points for cultural events in individual powiats of Łódź Province

The distribution of historical monuments is as follows: there are 101-150 historical monuments in 9 out of 24 powiats. The following powiats have more than 150: 213 in the powiat of Kutno, 218 in Łowicz and 599 in the city of Łódź. The powiats of Łask, Łódź East, Pabianice, Pajęczno, Wieruszów and Zduńska Wola have the smallest number of historical monuments
(Fig. 5). The powiats located in the northern, eastern and south-eastern parts of Łódź Province are the richest in monuments (Fig. 5). These powiats received 15 or 20 points on the four-grade bonitation scale. In the western part, the powiat which stands out is Sieradz. The powiats surrounding the capital of the province to the south are not rich in historical sites, which gave them the lowest score of 5 points.

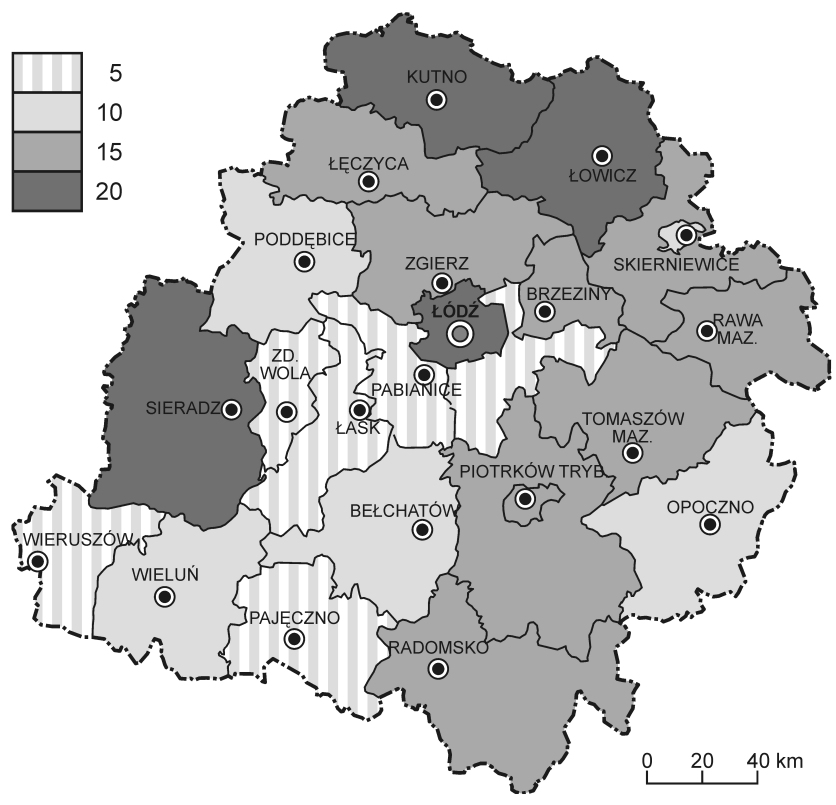

Figure 5. Bonitation points for the number of historical monuments in individual powiats of Łódź Province

The division of powiats into individual bonitation ranges is relatively even. Nine powiats stand out from the 24 of Łódź Province, featuring 11-15 historical sacred sites. They received 15 out of 20 points on a four-point scale. The least numerous are those with up to five sites. In five powiats, there are over 15 historical sites, however.

As regards sacred architecture, there is no observable tendency towards a concentration in the central part of the province, i.e. in Łódź. The largest number of points with respect to this variable were allocated to the powiats of Sieradz, Wielun, Radomsko, Kutno as well as to Łódź. There are 20, 19, 18 and 16 sacred historical monuments there, respectively. The smallest number was found in the town of Skierniewice and the powiats of Łódź East, Brzeziny and Zduńska Wola.

The city of Łódź received a total of 20 points, followed by four powiats with 50 bonitation points each (Tomaszów, Radomsko, Łowicz and Kutno). Skierniewice, the powiats of Łask and Pajęczno received 20 points and the remaining $25-45$ points. The lowest position was taken by the powiat of Zduńska Wola, with 15 points. The average number for all 24 powiats was 37 . 
The largest number of powiats (7) fall within the range of 37-47 points but in other ranges, the number is smaller (especially in the 15-25 range). The city of Łódź received the largest possible number of bonitation points (20) for each variable, whereas Zduńska Wola obtained three times fewer (5).

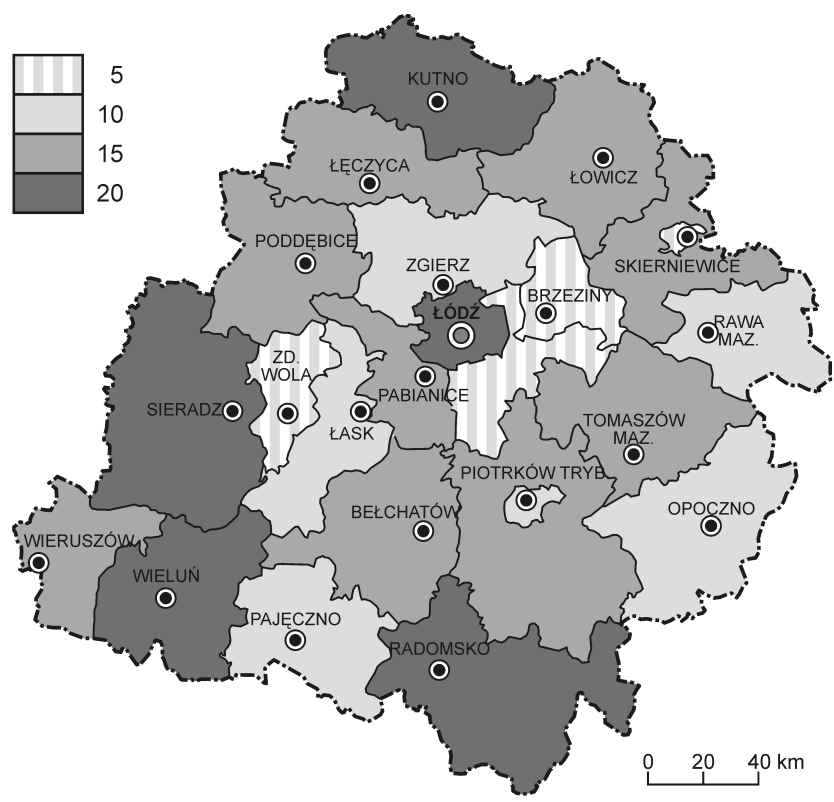

Figure 6. Bonitation points for the number of historical sacred sites in individual powiats of Łódź Province

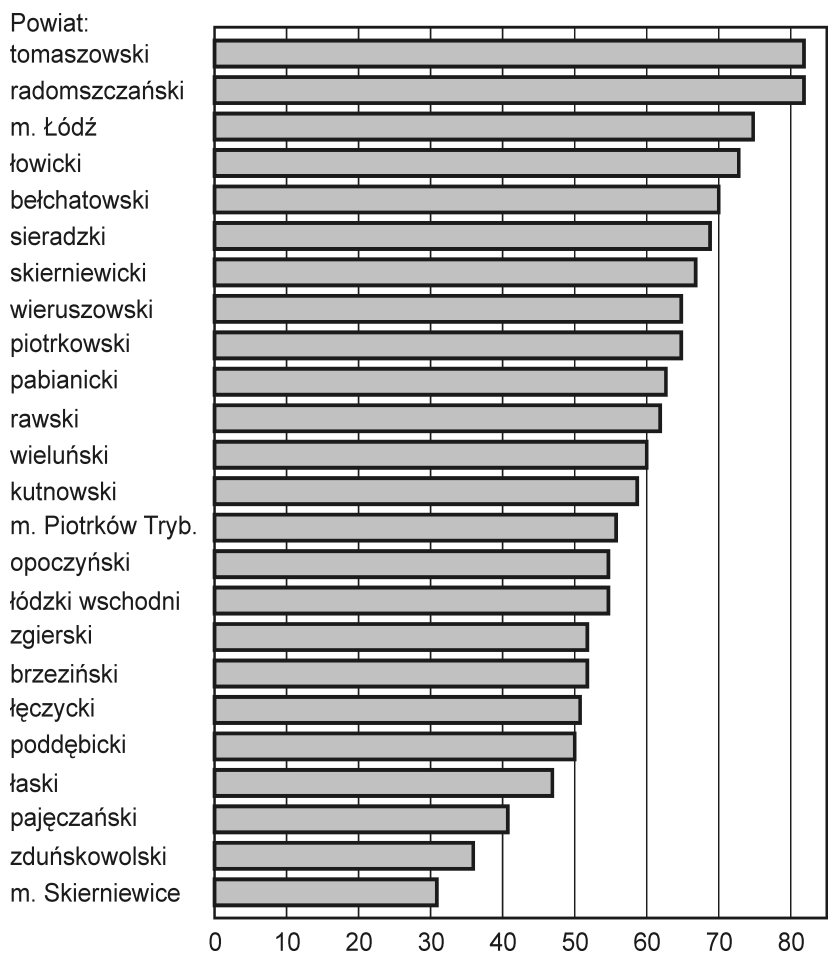

Figure 7. Ranking according to the total number of points for natural and human assets in individual powiats of Łódź Province
Fig. 7 presents the ranking of Łódź Province powiats based on the total number of bonitation points allocated for natural and human assets. In this case, the powiats of Tomaszów and Radomsko scored 82 points each, which is $85 \%$ of the maximum number (96).

The most numerous group consists of powiats which received 53-63 points and includes the powiats of Łódź East, Opoczno, Kutno, Wieluń, Rawa, Pabianice and the town of Piotrków Trybunalski. The smallest number (31-41) were allocated to very few powiats: the town of Skierniewice, and the powiats of Zduńska Wola and Pajęczno.

\section{TOURISM ASSETS \\ AND THE DISTRIBUTION OF TOURIST ACCOMMODATION IN ŁÓDŹ PROVINCE}

The article presents the correlation between individual natural and human assets and the number of hotel beds in the powiats of Łódź Province ${ }^{6}$.

Table 3. The correlation between selected tourism assets specified by the point bonitation method

and the distribution of tourist accommodation facilities

\begin{tabular}{|c|l|c|}
\hline No. & \multicolumn{1}{|c|}{ Tourism assets } & $\begin{array}{c}\text { Spearman's rank } \\
\text { correlation coefficient } \\
\text { for selected tourism } \\
\text { assets and the } \\
\text { distribution of tourist } \\
\text { accommodation } \\
\text { facilities }\end{array}$ \\
\hline 1 & Afforestation & 0.039 \\
\hline 2 & $\begin{array}{l}\text { Percentage of legally protected } \\
\text { areas }\end{array}$ & -0.138 \\
\hline 3 & $\begin{array}{l}\text { Occurrence of monuments of } \\
\text { nature }\end{array}$ & 0.457 \\
\hline 4 & Total of selected natural assets & 0.125 \\
\hline 5 & Number of cultural events & 0.277 \\
\hline 6 & Number of historical monuments & 0.228 \\
\hline 7 & Number of sacred historical sites & 0.298 \\
\hline 8 & Total of selected cultural assets & 0.381 \\
\hline
\end{tabular}

Source: authors

As shown in Table 3, the correlation between the distribution of tourist accommodation and human assets (0.381) is stronger than that between tourist accommodation and natural assets $(0.125)$. No correlation was found between afforestation and the number of hotel beds, nor between the percentage of legally protected areas and the distribution of tourist accommodation. The strongest relationship exists between the occurrence of monuments of nature and the distribution of tourist accommodation (0.457 - a moderate positive correlation). As regards human 
assets, the strongest correlation concerns the number of sacred sites (0.298), followed by cultural events $(0.277)$ and historical monuments $(0.228)$. The results show that the correlation is noticeable but low.

\section{SUMMARY AND CONCLUSIONS}

To sum up the analysis presented above, we should stress the fact that no correlation was found between afforestation and the number of hotel beds. The best example here is the city of Łódź, where afforestation is $9.3 \%$ but the number of beds is the largest in the whole province. Another example is the powiat of Opoczno, where, despite the highest afforestation among all 24 powiats of the province, there are only 174 hotel beds. On the other hand, a good example of this correlation is the powiat of Tomaszów, where the percentage of forest areas is the highest and it is reflected in the number of hotel beds.

There is no clear correlation between the legally protected areas and the distribution of accommodation. The powiats of Rawa and Bełchatów show the strongest correlation in this respect, contrary to the city of Łódź with the largest number of beds and a small percentage of legally protected areas (below $10 \%$ ). In the powiats of Tomaszów, Piotrków, Zgierz and the city of Łódź, we can notice a clear correlation between the number of nature monuments and the number of hotel beds. It can also be observed that the larger the number of cultural events is, the more hotel beds are available. This is the situation in Łódź, and the powiats of Bełchatów and Tomaszów.

The next asset is the number of historical monuments in individual powiats of the province. We may indicate powiats where a large number of hotel beds occur near historical monuments, e.g. Łódź, and the powiats of Rava, Bełchatów and Wielun. On the other hand, there are powiats (Łowicz and Kutno), where despite a large number of historical monuments, there are few hotel beds available.

A weak correlation was observed between the last human asset - the number of sacred historical sites in a powiat and the distribution of accommodation. A correlation between a large number of sacred historical sites and the number of hotel beds may be noticed in just a few powiats, for example in the powiat of Wieluń, with its 22 such sites and 1,154 hotel beds. The situation is similar in the town of Skierniewice, where there are three sacred historical sites and the number of beds is one of the smallest among the powiats (48).

The results enable us to provide answers to the research questions posed at the beginning of the article. Based on the analysis, it may be concluded that the result of the Spearman's rank correlation for natural assets does not support the hypothesis that they have the strongest impact on the distribution of tourist accommodation facilities in Łódź Province. The result for selected natural assets is 0.125 and for human assets -0.381 , which demonstrates that the latter have a stronger impact when it comes to the distribution of tourist accommodation facilities. While studying individual natural assets, it may be concluded that the number of monuments of nature has the strongest influence on the distribution of tourist accommodation. Hence, the second hypothesis assuming that areas protected by law have the strongest influence has not been confirmed. It leads to the conclusion that many tourism assets are not always accompanied by tourist accommodation facilities, although they are interdependent to some extent. In the case of Łódź Province, the distribution of tourist accommodation is more strongly affected by human than by natural assets.

\section{ENDNOTES}

1 The article was based on the MA thesis written by S. ŻAKOWSKA (2018).

2 The anthropogenic assets were competed with a list of sites placed in the register of Łódź Province historical monuments.

${ }^{3}$ As of 30 June 2017.

${ }^{4}$ As of 15 February 2018.

${ }^{5}$ The point bonitation scale was set at 5-20 for the higher clarity of the indicator.

6 The method used for the interpretation of results was presented in Statystyka: elementy teorii $i$ zadania (OSTASIEWICZ, RUSNAK, SIEDLECKA 1999).

\section{BIBLIOGRAPHY}

BALIŃSKA A., SIECZKO A., ZAWADKA J., 2014, Turystyka: wybrane zagadnienia, Difin, Warszawa.

BANASZCZYK P., TUMiŁOWICZ J., 2000, Arboretum w Rogowie, Multico Oficyna Wydawnicza, Warszawa.

BAR R., DOLIŃSKI A., 1978, Turystyka, Wydawnictwo Szkolne i Pedagogiczne, Warszawa.

BeETON S., 2005, Film-induced Tourism, Channel View Publications, Bristol.

BORZYSZKOWSKI J., 2011, Organizacja i zarządzanie turystyka w Polsce, CeDeWu, Warszawa.

DEREK M., 2010, Turystyka przemysłowa jako forma turystyki zrównoważonej, [in:] Z. Młynarczyk, I. Potocka, A. Zajadacz (eds.), Uwarunkowania i plany rozwoju turystyki, vol. 6: Turystyka zrównoważona, Bogucki Wydawnictwo Naukowe, Poznań, 31-41.

DEREK M., KOWALCZYK A., 2010, Zagospodarowanie turystyczne, Wydawnictwo Naukowe PWN, Warszawa.

DRABAREK A., 2011, Atrakcyjność turystyczna a rozmieszczenie bazy noclegowej w Indonezji w początkach XXI wieku, master thesis, Faculty of Geography and Regional Studies, University of Warsaw, Warsaw. 
DURYDIWKA M., DUDA-GROMADA K. (eds.), 2011, Przestrzeń turystyczna. Czynniki, różnorodność, zmiany, Uniwersytet Warszawski, Warszawa.

DYLIK J., DYLIK Z., KACZMAREK R., 1954, Województwo tódzkie: przewodnik turystyczny, Wydawnictwo "Sport i Turystyka", Warszawa.

GAWORECKI W., 2007, Turystyka, Polskie Wydawnictwo Ekonomiczne, Warszawa.

GOŁEMBSKI G. (ed.), 1999, Regionalne aspekty rozwoju turystyki, Wydawnictwo Naukowe PWN, Warszawa-Poznań.

GOŁEMBSKI G. (ed.), 2006, Kompendium wiedzy o turystyce, Wydawnictwo Naukowe PWN, Warszawa.

JĘDRYSIAK T., 2008, Turystyka kulturowa, Polskie Wydawnictwo Ekonomiczne, Warszawa.

KACZMAREK S., 2001, Rewitalizacja terenów poprzemystowych. Nowy wymiar w rozwoju miast, Wydawnictwo Uniwersytetu Łódzkiego, Łódź.

KOTER M., LISZEWSKI S., SULIBORSKI A., 1999, Łódź i region Polski środkowej: podręcznik wiedzy o regionie dla liceów, Łódzkie Towarzystwo Naukowe, Łódź.

KOWALCZYK A., 2001, Geografia turyzmu, Wydawnictwo Naukowe PWN, Warszawa.

KOWALCZYK A. (ed.), 2010, Turystyka zrównoważona, Wydawnictwo Naukowe PWN, Warszawa

KOŻUCHOWSKI K., 2005, Walory przyrodnicze w turystyce i rekreacji (Podręcznik akademicki), Wydawnictwo Kurpisz S.A., Poznań.

KRONENBERG M., 2012, Wptyw zasobów dziedzictwa przemystowego na atrakcyjność turystycznq miasta: przykład Łodzi, Wydawnictwo Uniwersytetu Łódzkiego, Łódź.

KRONENBERG M., 2016, Potencjat turystyczny dziedzictwa filmowego w województwie tódzkim, Centrum Inicjatyw na rzecz Rozwoju REGIO, Łódź.

KRUCZEK Z., 2005, Polska. Geografia atrakcji turystycznych, Wydawnictwo Proksenia, Kraków.

KRZYMOWSKA-KOSTROWICKA A., 1999, Geoekologia turystyki i wypoczynku, Wydawnictwo Naukowe PWN, Warszawa.

KUREK W. (ed.), 2007, Turystyka, Wydawnictwo Naukowe PWN, Warszawa.

KUROWSKI J.K., 2013, Obszary NATURA 2000 w województwie tódzkim, Regionalna Dyrekcja Ochrony Środowiska, Łódź.

LIJEWSKI T., MIKUŁOWSKI B., WYRZYKOWSKI J., 2002, Geografia turystyki Polski, PWE, Warszawa.

LISZEWSKI S., 2008, Urban areas as a subject for Polish tourism geography, Tourism/Turyzm, 18, 1, pp. 27-38.

ŁUKASZEWICZ A., 1987, Ogrody botaniczne $i$ arboreta w Polsce, Państwowe Wydawnictwo Rolnicze i Leśne, Warszawa.

MEDLIK S., 1995, Leksykon podróży, turystyki, hotelarstwa, PWN, Warszawa.

MOKRAS-GRABOWSKA J., 2014, Art-tourism space in Łódź: The example of the Urban Forms Gallery, Tourism/Turyzm, 24, 2, pp. 23-30.

Największe atrakcje turystyczne Łodzi i regionu tódzkiego, Regionalna Organizacja Turystyczna Województwa Łódzkiego, Oficyna Wydawniczo-Reklamowa SAGALARA, Łódź.

OLACZEK R., 2013, Ochrona przyrody w lasach Regionalnej Dyrekcji Lasów Państwowych w Łodzi i województwa tódzkiego, Oficyna Wydawnicza FOREST, Józefów.

OSTASIEWICZ S., RUSNAK Z., SIEDLECKA U., 1999, Statystyka: elementy teorii $i$ zadania, Wydawnictwo Akademii Ekonomicznej im. Oskara Langego, Wrocław.

PANASIUK A., SZOSTAK D., 2009, Hotelarstwo. Ustugi - eksploatacja - zarzadzanie, Wydawnictwo Naukowe PWN, Warszawa.

PAWLIKOWSKA-PIECHOTKA A., 2009, Zagospodarowanie turystyczne i rekreacyjne, Wydawnictwo Novae Res, Gdynia.
PIRASZEWSKA K., 2004, Przyrodnicze uwarunkowania rozmieszczenia turystycznej bazy noclegowej w Tajlandii, master thesis, Faculty of Geography and Regional Studies, University of Warsaw, Warsaw.

Program rozwoju turystyki w województwie łódzkim na lata 20072020, 2007, Warszawa-Łódź.

PRZECŁAWSKI K., 1997, Cztowiek a turystyka. Zarys socjologii turystyki, Wydawnictwo Albis, Kraków.

Państwowe Gospodarstwo Leśne Lasy Państwowe, 2017, Raport o stanie lasów w Polsce 2016, Centrum Informacyjne Lasów Państwowych, Warszawa.

ROGALEWSKI O., 1972, Podstawy gospodarki przestrzennej w turystyce, ser. Ruch Turystyczny - Monografie, 13, Szkoła Główna Planowania i Statystyki, Warszawa.

SOŁOWIEJ D., 1992, Podstawy metodyki oceny środowiska przyrodniczego cztowieka, Wydawnictwo Naukowe Uniwersytetu im. Adama Mickiewicza, Poznań

Strategia Rozwoju Województwa Łódzkiego 2020, Zarząd Województwa Łódzkiego, 2006, Łódź.

Strategia Rozwoju Województwa Łódzkiego na lata 2007-2020, Zarząd Województwa Łódzkiego, 2006, Łódź.

SZWICHTENBERG A. (red.), 2000, Podstawy turystyki, Politechnika Koszalińska, Koszalin.

TERTELIS P., 2012, Walory turystyczne a rozmieszczenie bazy noclegowej w Nepalu na poczatku XXI wieku, master thesis, Faculty of Geography and Regional Studies, University of Warsaw, Warsaw.

Ustawa z dnia 29 sierpnia 1997 r. o ustugach turystycznych, DzU nr 133, poz. 884 ze zmianami.

WARSZYŃSKA J., JACKOWSKI A., 1978, Podstawy geografii turyzmu, PWN, Warszawa.

WIĘCKOWSKI M., 2014, Tourism space: An attempt at a fresh look, Tourism/Turyzm, 24, 1, pp. 17-24.

WŁODARCZYK B., 2009, Przestrzeń turystyczna. Istota, koncepcje, determinanty rozwoju, Wydawnictwo Uniwersytetu Łódzkiego, Łódź

WŁODARCZYK B., 2014, Space in tourism, tourism in space: On the need for definition, delimitation and classification, Tourism/ Turyzm, 24,1, pp. 25-34.

WODEJKO S., 1997, Ekonomiczne zagadnienia turystyki, Wyższa Szkoła Handlu i Prawa, Warszawa.

ŻAKOWSKA S., 2018, Walory turystyczne a rozmieszczenie turystycznej bazy noclegowej w województwie w tódzkim, master thesis, Faculty of Geography and Regional Studies, University of Warsaw, Warsaw.

www.arboretum.sggw.pl/historia.html; $15.05 .2018 \mathrm{r}$. www.arboretum.sggw.pl/polozenie.html; $15.05 .2018 \mathrm{r}$ www.bdl.stat.gov.pl; 22.05.2018 r. www.czasnarower.pl; 22.05.2018 r.

www.ec.europa.eu/culture/european-year-cultural-heritage-20

18_en; 10.12 .2017 r.

www.erih.net; 02.12.2017 r.

www.historycznie.uni.lodz.pl/poczatek.htm; 18.04.2018 r. www.hotelarze.pl/hot/bl-hotelarstwo-18w.php; 19.04 .2018 r. www.kajaki.pttk.pl/index.php?id=turystyka-kwalifikowana; 20.04.2018 r.

www.kampinoski-pn.gov.pl/edukacja/ohz-w-smardzewicach; 24.05.2018 r

www.klubgaja.pl; 04.04.2018 r.

www.kreatywna-europa.eu/europejski-rok-dziedzictwa-kultu rowego-2018/;02.12.2017 r.

www.ktpzg.pttk.pl/szlaki/szlaki.php; 15.11.2017 r.

www.kultura.lodz.pl; 18.04 .2018 r.

www.lodz.pttk.pl; 15.11.2017 r. 
www.lodzkie.travel/?kat=ochrona_przyrody\&sub=7\&sort=n; 10.12.2017 r.

www.lodzkie.travel/?kat=swiatynie; $13.04 .2018 \mathrm{r}$.

www.mapa.lodz.pl/portal/apps/webappviewer/index.html?id $=7489987 \mathrm{eb} 60 \mathrm{a} 4369814 \mathrm{e} 53 \mathrm{~d} 49 \mathrm{cc} 58 \mathrm{ffc} \&$ extent $=19.317,51.7126$,

$19.6459,51.8507 ; 18.04 .2018 \mathrm{r}$.

www.nieborow.art.pl/ogrody/; 28.03.2018 r.

www.nieborow.art.pl/o-muzeum/historia-palacu/; $28.03 .2018 \mathrm{r}$. www.nieborow.art.pl/o-muzeum/www.wuoz-lodz.pl; 28.03. $2018 \mathrm{r}$.

www.parkilodzkie.pl/npk/edukacja/spalski-park-krajobrazowy; 22.05.2018 r.

www.parkilodzkie.pl/npk/przedborski-pk; $22.05 .2018 \mathrm{r}$.

www.parkilodzkie.pl/npk; 22.05.2018 r.

www.parkilodzkie.pl/pkwl/o-parku/kultura; 22.05.2018 r.

www.parkilodzkie.pl/pkwl/turystyka/leksykon?start=10; 22.05 . $2018 \mathrm{r}$.

www.parkilodzkie.pl/pkwl/turystyka/szlaki-turystyczne/278zielony-szlak-pieszy-po-parku-krajobrazowym-wzniesienlodzkich; 22.05.2018 r.

www.parkilodzkie.pl/pkwl/turystyka/szlaki-turystyczne/345czarny-szlak-rowerowy-po-pkwl-opis-trasy-z-kilometrazem 22.05.2018 r. www.parkilodzkie.pl/pkwl/turystyka/szlaki-turystyczne; 22.05. $2018 \mathrm{r}$.

www.parkilodzkie.pl/spk/pk-miedzyrzecza-warty-i-widawki; 22.05.2018 r.

www.parkilodzkie.pl/spk/zaleczanski-pk; 22.05 .2018 r.

www.pl.cit.lodz.pl/pokaz/1266,5,97, szlak-rowerowy-po-parkukrajobrazowym-wzniesien-lodzkichwww.regiocentrum.pl; 22.05.2018 r

www.pl.cit.lodz.pl/pokaz/1266,5,97,szlak-rowerowy-po-parkukrajobrazowym-wzniesien-lodzkich; 25.05.2018 r.

www.pl.cit.lodz.pl/pokaz/1321,8,97,szlaki-rowerowe-lasu-lagie wnickiego; 25.05.2018 r.

www.pttk.pl/kznw/kanon.php; 20.05.2018 r.

www.regiocentrum.pl/pobierz/szlak-filmowy-wojewodztwalodzkiego.pdf; 28.05.2018 r.

www.turystyka.wielun.pl; 22.05.2018 r.

www.turystyka.wielun.pl/pl/poi/3273263; 22.05.2018 r.

www.turystyka.wielun. $\mathrm{pl} / \mathrm{pl} /$ search?query=Przedborski+Park +Krajobrazowy; 22.05.2018 r.

www.turyzm.pl; 20.12.2017 r.

www.uml.lodz.pl/czas-wolny/zielen-i-rekreacja/ogrod-botani czny; 15.05.2018 r.

www.wuoz.bip.lodz.pl/page/12,zabytki.html; 18.04.2018 r.

Article received:

15 August 2018

Accepted:

28 September 2018 